\title{
ANALISIS PENINGKATAN KAPASITAS PRODUKSI PADA PROSES PEMBUATAN FRAME MOTOR KLX DENGAN METODE LINE BALANCING DI PT.KMI
}

\author{
Denny Siregar ${ }^{1}$, Abdul Yasid ${ }^{2}$ \\ ${ }^{1}$ Dosen Teknik Industri, Fakultas Teknik, Universitas Bhayangkara Jakarta Raya \\ ${ }^{2}$ Mahasiswa Teknik Industri, Fakultas Teknik, Universitas Bhayangkara Jakarta Raya \\ siregar1973@gmail.com, yasidbushri@gmail.com
}

\begin{abstract}
Abstrak
PT. KMI merupakan industri manufaktur yang bergerak di bidang industri otomotif roda dua (sepeda motor) Dalam proses produksi terjadi masalah waktu menganggur (idle time) di stasiun kerja masing-masing yang terjadi pada lintasan kerja diline 1 KLX. Oleh karena itu perlu dilakukan penyeimbangan lintasan kerja pada proses pembuatan frame motor KLX, salah satunya dengan menggunakan metode line balancing Ranked Position Weigth (RPW).Dengan mengalokasikan beban kerja yang berlebihan kepada beban kerja yang sedikit maka akan menghasilkan lintasan yang seimbang, dari hasil perhitungan line balancing maka didapat waktu siklus yang merata, efisiensi naik menjadi 97,83\% dari efisiensi awal 93,86\% dan Balance delay awal 6,14\% menjadi 2,17 $\%$. kapasitas produksi yang meningkat yang awalnya 55 unit per-8 jam kerja menjadi 58 unit per- 8 jam kerja.
\end{abstract}

Kata Kunci : Penyeimbang lintasan kerja, Efisiensi

\begin{abstract}
PT KMIis the manufacture industry which runs in the two wheels automotive product. In the production process there are a lot of problems regarding about the idle time in each job line that happens in the 1 KLX job line. Therefore, it is needed to do the job line balance in the KLX frame motor production. One of it by using line balancing Ranked position weight method. By allocating the job's loading that is overrated to the small job's loading so it will produce the balanced line, from the line balancing's calculation there is the result of the balanced rotation from the $97.83 \%$ efficiency of the first $93.86 \%$ efficiency and the firstbalanced delay $6.14 \%$ to be $2.17 \%$. So it will result the production capacity that increase previously 55 units/8 working hours becomes 58 units.
\end{abstract}

Key Words : Line balancing's method, Efficiency

\section{PENDAHULUAN}

Perkembang teknologi dan persaingan bisnis yangsemakin ketat, semakin mendorong perusahaan industri otomotif roda dua berlomba-lomba dalam menciptakan produk yang berkualitas. Semakin tingginya permintaan konsumen terhadap produk dengan kualitas yang semakin meningkat, maka semua perusahaan berusaha dalam meningkatkan kapasitas produksinya, untuk memenuhi permintaan konsumen dan meningkatkan keuntungan.

Untuk meningkatkan kapasitas produksi salah satu caranya adalah dengan pemanfaatan sumber daya yang tersedia seoptimal mungkin untuk menghasilkan produk yang maksimal, tanpa mengurangi kualitas dan kuantitas dari produk tersebut. Para pelaku industri otomotif melakukan cost reduction mulai dari memodifikasi proses, memodifikasi urutan kerja, memodifikasi lay out, menurunkan biaya over time dan lain-lain yang bertujan untuk memaksimalkan keuntungan yang diperoleh perusahaan tersebut.

PT. KMI merupakan salah satu perusahaan manufaktur yang bergerak di bidang otomotif roda dua yang memproduksi sepeda motor seperti Ninja, Trail (KLX). Dengan Produksi rata-rata $6.000-8.500$ unit motor perbulannya, pada tipe Motor KLX. Dengan permintaan konsumen yang tiap bulannya terus meningkat terhadap motor KLX,akan berdampak pula pada produksi pembuatan frame motor yang telah melebihi kapasitas produksi di bagian welding, maka peningkatan kapasitas produksi di bagian welding harus dilakukan peningkatan kapasitas produksi. Peningkatan kapasitas produksi dapat 
dilakukan dengan menambah jam kerja lembur, penambahan giliran kerja (shift), penambahan mesin dan alat, memodifikasi tempat kerja atau penambahan tempat (layout),melakukan perubahan proses urutan kerja (sop) dan keseimbangan lintasan (line balancing). Dengan peningkatan produksi diharapkan oleh perusahaan dapat memenuhi permintaan konsumen dan meningkatkan keuntungan.Dibawah ini adalah gambar permintaan konsumen terhadap MotorKLX dari bulan September 2015 sampai Februari 2016.

Tabel 1.Order Motor KLX dan Actual Produksi

\begin{tabular}{llcc}
\hline No. & Bulan & $\begin{array}{c}\text { Permintaan } \\
\text { Order } \\
\text { Motor KLX }\end{array}$ & $\begin{array}{c}\text { Aktual } \\
\text { Produksi }\end{array}$ \\
\hline 1 & September & 7.562 & 6.708 \\
\hline 2 & Oktober & 8.415 & 6.708 \\
\hline 3 & November & 8.200 & 6.708 \\
\hline 4 & Desember & 8.532 & 6.708 \\
\hline 5 & Januari & 7.853 & 6.708 \\
\hline 6 & Febuari & 8.475 & 6.708 \\
\hline
\end{tabular}

Tingginya permintaan produk tersebut merupakan suatu hal yang perlu diantisipasi, karena apabila tidak diantisipasi biaya operasional produksi akan bertambah dikarenakan banyak hal seperti over time tinggi, over head produksi tinggi, dan lain-lain. Kondisi saat ini proses produksi pembuatan Frame Motor KLX dibagian welding hanya mencapai 1.144 unit perbulannya pada line satu. Adapun keadaan kondisi pada line satu proses pembuatan frame motor sekarang adalah dengan cycle time 8,61 menit atau 517detik. Dengan komposisi man power sebanyak 11 orang. Selama ini ada hambatan bottelneck pada aliran prosespembuatan frame motor KLX, karena lintasan produksi yang ada saat ini perlu diseimbangkan supaya menghasilkan nilai Balanced Delay yang lebih kecil dan efisiensi lebih optimum. Berdasarkan pengamatan yang dilakukan pada proses produksi yang berlangsung di line satu KLX, proses produksi belum berjalan dengan baik sehingga mengakibatkan ketidakseimbangan lintasan. Ketidakseimbangan lintasan dalam kegiatan produksi dapat dilihat dari menganggurnya beberapa stasiun kerja, sedangkan di stasiun kerja lainnya tetap bekerja secarapenuh. Hal ini disebabkan oleh adanya idle time di salah satu stasiun kerja, untuk menyelesaikan pekerjaan lebih cepat dari stasiun lainnya. Dari 11 stasiun kerja terdapat 1 stasiun kerja yang mengalami idle time pada stasiun kerja, Forward in jig yang mengakibatkan pengerjaannya lebih cepat dari stasiun kerja lainnya. Dengan adanya idle time dengan selisih 197 detik terhadap cycle time 517 detik yang mengakibatkan proses pembutan frame motor KLX menjadi terhambat.

Permasalah diatas, dapat diidentifikasi bahwa kapasitas produksi dibagian welding tidak bisa memenuhi schedule produksi yang berdampak tidak terpenuhi permintaan konsumen dan terdapat idle time di salah satu stasiun kerja yang menyebabkan beban kerja tidak merata pada stasiun kerja lainnya. Kemudian rumusan masalahnya sebagai berikut:

1. Bagaimana caranya meningkatkan produksi dan jadwal produksi yang normal?

2. Bagaimana upaya perusahaan untuk menghilangkanidle time tidak terjadi di proses pembuatan frame Motor KLX?

3. Bagaimana cara memodifikasi proses urutan kerja agar beban kerja merata, di setiap lini produksi?

Adapun tujuan penelitian ini adalah guna memperbaiki proses produksi yang mengalami idle time di line 1 KLX dengan metode line balancing, untuk meningkatkan kapasitas produksi, meminimalkan waktu tunggu / idle time dengan mengalokasikan beban kerja yang berlebihan. Yang dibatasi dengan area kerja yakni di PT Kawasaki Motor Indonesia dan fokus pada line 1 pembuatan frame motor KLX dengan 8 jam kerja, analisis data dilakukan dengan penerapan line balancing di line 1 pembuatan frame motor KLX, penelitian dilakukan mulai bulan April 2016 sampai dengan Juli 2016, tidak sampai dengan perhitungan biaya dan dengan asumsi yakni layout, mesin dan alat, serta formasi operator sudah baik.

$$
\text { Linebalancing merupakan }
$$
penyeimbangan penugasan elemen-elemen tugas dari suatu assembly line ke work stations untuk meminimumkan banyaknya work station dan meminimumkan total harga idle time pada semua stasiun untuk tingkat output tertentu (Gaspersz,2004). Dalam penyeimbangan tugas ini, kebutuhan waktu per-unit produk yang 
dispesifikasikan untuk setiap tugas dan hubungan sekuensial harus dipertimbangkan.Fungsi dari Line balancing adalah membuat suatu lintasan yang seimbang. Tujuan pokok dari penyeimbangan lintasan adalah meminimumkan waktu menganggur (idle time) pada lintasan yang ditentukan oleh operasi yang paling lambat (Baroto, 2002).

Manajemen industri dalam

menyelesaikan masalah line balancing harus mengetahui tentang metode kerja, peralatan peralatan, mesin-mesin, dan yang digunakan dalam proses kerja. Data yang diperlukan adalah informasi tentang waktu yang dibutuhkan untuk setiap assembly line dan precedence relationship. Aktivitas-aktivitas yang merupakan susunan dan urutan dari berbagai tugas yang perlu dilakukan,manajemen industri perlu menetapkantingkat produksi per hari yang disesuaikan dengan tingkat permintaan total, kemudian personil membaginya ke dalam waktu produktif yang tersedia per hari. Hasil ini adalahcycle time yang merupakan waktu dari produk yang tersedia pada setiap stasiun kerja work station (Baroto,2002).

Dengan adanya persamaan kapasitas untuk setiap stasiun yang berbeda maka hasil yang diharapkan dari proses line balancing adalah:

1 Menghindari penumpukan barang dalam proses pada suatu bagian produksi.

2 Menghindari penganguran pada bagian produkasi lainnya.

3 Mendapatkan efisien sistem yang cukup tinggi.

4 Memenuhi rencana produksi yang telah ditetapkan.

Terdapat sejumlah langkah pemecahan masalah line balancing antara lain : mengidentifikasi tugas-tugas individual atau aktivitas yang akan dilakukan, menentukan waktu yang dibutuhkan untuk melaksanakan setiap tugas itu, menetapkan precedence constraints, jika ada yang berkaitan dengan setiap tugas itu, menentukan out put dari assembly line yang dibutuhkan, menentukan waktu total yang tersedia untuk memproduksi output, menghitung cycle time yang dibutuhkan, misalnya: waktu diantara penyelesaian produk yang dibutuhkan untuk menyelesaikan output yang diinginkan dalam batas toleransi dari waktu (batas waktu yang yang diijinkan), memberikan tugas-tugas kepada pekerja atau mesin, menetapkan minimum banyaknya stasiun kerja (work stasion) yang dibutuhkan untuk memproduksi out put yang diinginkan (Gaspersz, 2004).

Metode penyeimbangan lini perakitan ada yang disebut Ranked Posision Weight $(R P W)($ Baroto, 2002), dengan langkah sebagai berikut :

1 Buat precedence diagram untuk tiap proses.

2 Tentukan bobot posisi untuk masing-masing elemen kerja yang berkaitan dengan waktu operasi untuk waktu pengerjaaan yang terpanjang dari mulai operasi permulaan hingga sisa operasi sesudahnya.

3 Membuat rangking tiap elemen pekerjaan berdasarkan bobot posisi di langkah dua. Pengerjaan yang memilki bobot terbesar diletakkan pada rangking pertama.

4 Tentukan waktu siklus. Pilih elemen operasi dengan bobot tertinggi, alokasikan kestasiun kerja. Jika masih layak(waktu stasiun < CT), alokasikan operasi dengan bobot tertinggi berikutnya, namun alokasi ini tidak boleh membuat waktu stasiun $>$ CT .

5 Bila alokasi suatu elemen operasi membuat waktu stasiun $>\mathrm{CT}$, maka sisa waktu ini (CT-ST) dipenuhi dengan alokasi elemen operasi dengan bobot paling besar dan penambahannya tidak membuat ST $>$ CT.

\section{METODOLOGI PENELITIAN}

Adapun metode penelitian yang digunakan ialah Penelitian kualitatif adalah ekplorasi yang digunakan untuk memperoleh pemahaman tentang alasan yang mendasari, opini dan motivasi.Dengan jenis penelitian deskriptif yang cenderung kepada analisis dan fokus pada fakta di lapangan.

Adapun teknik pengumpulan data berdasarkan pengelompokan data berikut :

1. Lokasi : lintasan perakitan frame motor KLX line 1 bagian produksi PT. KMI, Kawasan Industri 
MM2100,Jl. Madura Blok L 11, Cikedokan, Cibitung, Bekasi.

2. Jenis data :

a. Data pokok (primer) adalah data yang diperoleh langsung dari PT. KMI, di bagian produksi pada proses pembuatan frame motor KLX.

b. Data pelengkap (sekunder) adalah data yang diperoleh dari, jurnal atau arsip-arsip atau dari data-data bahan pustaka yang berhubungan dengan pokok permasalahan yang akan diteliti oleh peneliti, yang bersumber dari PT. KMI.

Kemudian, menyangkut pengumpulan data dilapangan, data-data yang dimaksud adalah data flow process perakitan frame motor KLX dimana peneliti melakukan penelitian, data elemen kerja dan urutan kerja pada masingmasing stasiun kerja, data pada setiap stasiun kerja dan operator pada line 1 assembling frame motor KLX, dan data waktu pada setiap proses elemen kerja.

\section{Pengukuran Jam Kerja Yang Tersedia}

Melakukan pengukuran waktu kerja secara langsung dengan (stop watch time study).Langkah yang dilakukan dalam melakukan penelitian pendahuluan dengan melihat kondisi langsung dilapangan, menentukan setiap stasiun kerja mana saja yang akan diukur, menentukan operator yang akan diukur waktu kerjanya. Dalam menentukan operator penulis mempunyai kriteria memilih pekerja yang bekerja secara wajar dan tidak di buat-buat, kemudian peneliti melatih operator sesuai dengan petunjuk kerja yang seharusnya yang telah dibuat oleh perusahaan, dan yang terakhir adalah penulis menyiapkan alat yang akan digunakan dalam pengukuran waktu yaitu : stopwatch, pensil, dan form pengamatan. Hasil dari pengukuran tersebut akan dicatat dan divalidasi oleh manager produksi dan kemudian akan di olah atau dianalisis.

Berikut ini adalah langkah-langkah atau tahapan proses pengukuran waktu kerja dengan metode pengukuran langsung (stop watch time study).

1. Penetapan tujuan pengukuran.
2. Melakukan penelitian pendahuluan.

3. Memilih operator.

4. Melatih operator.

5. Mengurangi pekerjaan atas elemen pekerjaan.

6. Melakukan pengukuran pendahulu.

7. Menyiapkan alat-alat pengukuran.

8. Dalam tahap ini jumlah pengukuran awal ditetapkan oleh pengukur.

9. Menghitung kecukupan data dengan tujuan untuk melihat apakah data yang sudah dikumpulkan sudah cukup atau belum.

10. Jika pengukuran belum cukup maka hasil pengukuran ditambah lagi.

11. Menghitung standar deviasi sebenarnya dari waktu penyelesaian pekerjaan.

12. Menentukan batas kendali atas dan batas kendali bawah.

13. Melakukan penghitungan waktu siklus.

14. Melakukan perhitungan waktu normal.

15. Melakukan perhitungan waktu baku.

\section{Urutan Proses Produksi}

Melakukan pengamatan kerja secara langsung terhadap urutan proses produksi yang dikerjakan operator pada pembuatan frame KLX, untuk memudahkan pengelolahan data.

\section{Analisis Sistem yang Sudah Berjalan}

Critical performance measures adalah pengukuran batas kritis performance pada perusahaan pada departemen produksi, pengukuran ini dilihat dari kondisiawal stasiun kerja (line efficiency), Pengukuran kritis ini selanjutnya mengarah kepeda pengukuran efisiensi dan keefektifitas dari tiap-tiap stasiun kerja. Analisissystem berjalan dilakukakan dengan mengamati kondisi langsung dilapangan padadepartemen produksi.Saat pengamatan dilakukan, perlu dibuatkan Peta Proses Operasi (PPO). Peta proses operasi merupakan diagram yang menggambarkan tahap-tahap proses yang dialami bahan baku (material) pada proses 
produksi yang meliputi urutan proses operasi dan pemeriksaan. PPO ini berisi informasi mengenai:

1. Deskripsi proses elemen-elemen kerja.

2. Waktu penyelesaian masingmasing elemen kerja.

3. Peralatan-peralatan yang diperlukan untuk penyelesaian pekerjaan tersebut.

Apabila sistem telah berjalan dengan baik, maka dapat disimpulkan dengan keadaan produksi yang sudah berjalan baik pula dan untuk penyempurnaanya dapat diberikan saran yang bermanfaat.Maka jika sistem yang berjalan ternyata tidak sesuai dengan standar perusahaan, atau terjadi ketidaksesuaian antara hasil actual dengan target yang ditentukan, maka langkah selanjutnya adalah mencari factor penyebabnya dan melakukan upaya meminimasi ketidak sesuian tersebut.

\section{Metode Line Balancing RPW (Ranked Positional Weight)}

Berdasarkan hasil pengamatan yang dilakukan maka akan dianalisis dengan metode keseimbangan lini disetiap stasiun kerja. Salah satu aplikasi dari ditemukannya waktu standar atau waktu baku adalah untuk menyeimbangkan lintasan produksi.

Langkah-langkah yang diperlukan dalam melakukan penyeimbangan lintasan adalah menentukan hubungan antara pekerjapekerja yang terlibat dalam suatu lintasan produksi dan hubungan keterkaitan antara pekerja tersebut yang digambarkan dalam precedence diagram.

Waktu menunggu. (Idle Time), dimana operator atau pekerja menunggu untuk melakukan proses kerja ataupun kegiatan operasi yang selanjutnya akan dikerjakan. Selisih atau perbedaan antara Cycle time (CT) dan Stasiun Time (ST), atau CT dikurangi Stasiun Time (ST).

$$
\text { Idle Time }=n W_{s}-\sum_{i=1}^{n} W_{i}
$$

Keterangan:

$\mathrm{n} \quad=$ Jumlah stasiun kerja.

Ws $=$ Waktu stasiun kerja terbesar.

$\mathrm{W} i=$ Waktu sebenarnya pada stasiun kerja.

$i=1,2,3, \ldots$, n.

Keseimbangan Waktu Senggang. (Balance Delay), merupakan ukuran dari ketidak efisiennya lintasan yang dihasilkan dari waktu mengganggur sebenarnya yang disebabkan karena pengalokasian yang kurang sempurna diantar astasiun-stasiun kerja. Balance delay dapat dirumuskan sebagai berikut:

$$
D=\frac{n \cdot C-\sum t_{i}}{\left(n t_{i}\right)} \times 100 \%
$$

Keterangan:

$\mathrm{C}=$ Waktu siklus.

$\mathrm{D}=$ Balance delay $(\%)$.

$\mathrm{N}=$ Jumlah stasiun kerja.

$\Sigma \mathrm{t} i=$ Jumlah semua waktu operasi.

$\mathrm{T} i=$ Waktu operasi.

Efisiensi stasiun kerja, merupakan rasio antara waktu operasi tiap stasiun kerja (Wi) dan waktu operasi stasiun kerja terbesar (Ws). Efisiensi stasiun kerja dapat dirumuskan sebagai berikut:

$$
\text { Efisiensi stasiun kerja }=\frac{W_{i}}{W_{s}} \times 100 \%
$$

Line efficiency, merupakan rasio dari total waktu stasiun kerja dibagi dengan siklus dikalikan jumlah stasiun kerja atau jumlah efisiensi stasiun kerja dibagi jumlah stasiun kerja. Line efficiency dapat dirumuskan sebagai berikut:

$$
\text { Line Efficiency }=\frac{\sum_{\mathrm{i}=1}^{k} \mathrm{STi}}{(K)(C T)} \times 100 \%
$$

Keterangan:

$\mathrm{STi}=$ Waktu stasiun kerja dari ke-i.

$\mathrm{K}=$ Jumlah stasiun kerja.

$\mathrm{CT}=$ Waktu siklus. 
Work Station, merupakan tempat pada lini perakitan dimana proses perakitan dilakukan.Setelah menentukan interval waktu siklus, maka jumlah stasiun kerja yang efisien dapat ditetapkan dengan rumus:

$$
K \min =\frac{\sum_{i=1}^{k} t i}{C}
$$

Keterangan:

$\mathrm{ti}=$ Waktu operasi (elemen).

$\mathrm{C}=$ Waktu siklus stasiun kerja.

$\mathrm{Kmin}=$ Jumlah stasiun kerja minimal.

Smoothes index (SI), adalah suatu indeks yang menunjukkan kelancaran relative dari penyeimbangan lini perakitan tertentu.

$$
S I=\sqrt{\sum_{i=1}^{K}\left(S T i_{\text {maks }}-S T i\right)^{2}}
$$

Keterangan:

ST maks = Maksimum waktu di stasiun

Sti = Waktus tasiun di stasiun kerja ke-i.

\section{Metode 5W-1H}

Untuk mengembangkan rencana tindakan untuk mengatasi berat beban yang tidak seimbang (Weight of Product) pada factor operator memakai $5 \mathrm{~W} 1 \mathrm{H}$ yang pada umumnya mempertanyakan dan menyelidiki sebuah proses yang dilaksanakan apakah sudah efektif dan efisien.

\section{Usulan Perbaikan Keseimbangan Lintasan}

Rencana usulan perbaikan lintasan di line motor KLX dengan maksud untuk mengetahui penerapan metode penyelesaian masalah yang diusulkan, apakah dalam penerapan masih banyak hambatan atau kekurangan dengan demikian maka metodeyang diterapkan tersebut dapat dilakukan setelah didapat dari hasil keseimbangan lintasan.

\section{HASIL DAN PEMBAHASAN}

\section{Gambaran Umum Perusahaan}

PT.KMI berdiri di Indonesia pada tanggal 18 Februari 1994, dan beralamat di Jl. Perintis Kemerdekaan, Kelapa Gading Jakarta Utara 14250. Perusahaan KMI ini mempunyai cabang yang berlokasi di, Kawasan Industri MM 2100, Jl.Madura Blok L 11, Cikedokan, Cibitung, Bekasi.Perusahaan ini merupakan perusahaan joint venture antara perusahaan Jepang dengan perusahaan Indonesia.

\section{Gambaran Umum Produk}

Frame motor merupakan sparepart utama dalam pembuatan Motor KLX, yang diproduksi secara terpisah dengan perakitan body motor. Di bagian welding khususnya hanya memproduksi bagian-bagian frame, perakitan seluruh komponen-komponen dengan cara pengelasan. Gambar 1 adalah gambar frame motor KLX.

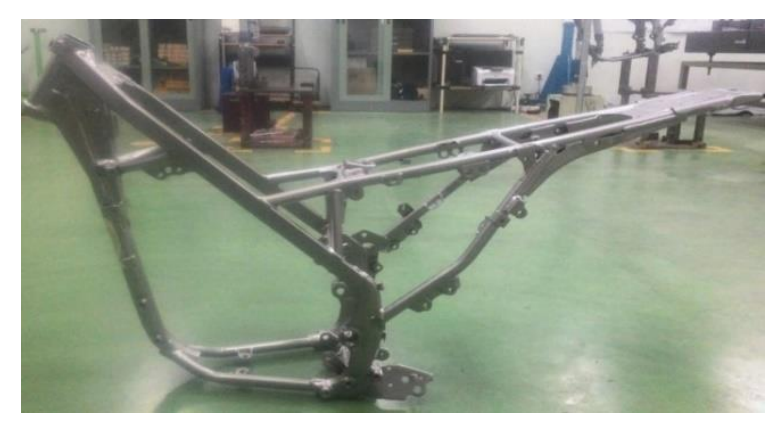

Gambar 1. Frame Motor KLX

\section{Lintasan Perakitan Produksi Frame Motor KLX}

Gambaran lintasan perakitan frame motor KLX dibagian welding pada line 1 seperti terlihat pada gambar 2.

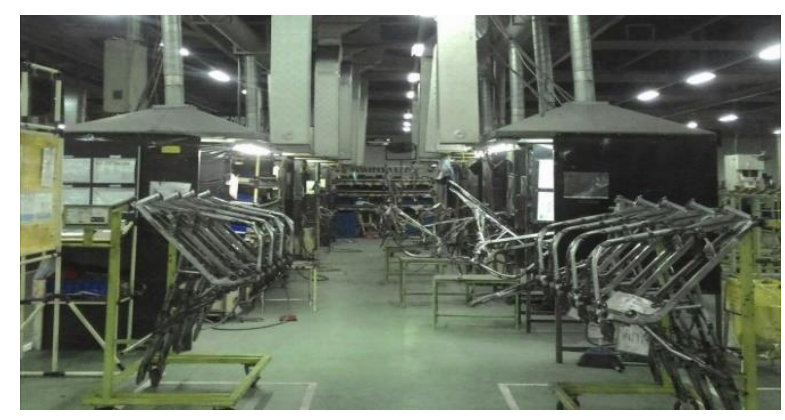

Gambar 2. Stasiun kerja frame motor KLX. Sumber : PT.KMI

Pada lintasan perakitan produksi frame motor KLX, terdapat 11 stasiun kerja dengan jumlah 11 operator dengan spesifikasi pekerjaan yang berbeda-beda pada tabel dapat dilihat spesifikasi secara umum untuk masingmasing operator yang bekerja pada saat ini. 
Tabel 2. Spesifikasi Umum Pekerjaan di TiapTiap Stasiun Kerja (Sumber: PT. KMI)

\begin{tabular}{|c|c|c|}
\hline $\begin{array}{c}\text { Stasiun } \\
\text { Kerja }\end{array}$ & $\begin{array}{l}\text { Jumlah } \\
\text { Operator }\end{array}$ & Spesifikasi \\
\hline I & 1 & $\begin{array}{l}\text { Melakukan proses } \\
\text { pengelasan sub RH in jig }\end{array}$ \\
\hline II & 1 & $\begin{array}{l}\text { Melakukan proses } \\
\text { pengelasn sub LH in jig }\end{array}$ \\
\hline III & 1 & $\begin{array}{l}\text { Melakukan proses } \\
\text { pengelasan sub RH dan } \\
\text { LH bagian dalam. }\end{array}$ \\
\hline IV & 1 & $\begin{array}{l}\text { Melakukan proses } \\
\text { pengelasan forwad in jig }\end{array}$ \\
\hline $\mathbf{V}$ & 1 & $\begin{array}{l}\text { Melakukan proses } \\
\text { pengelasan cross part } \\
\text { bagian dalam frame dan } \\
\text { pengelasan full forwad out } \\
\text { jig }\end{array}$ \\
\hline VI & 1 & $\begin{array}{l}\text { Melakukanproses } \\
\text { perakitan pengelasn } \\
\text { semua komponen } 1,2,3,4,5 \\
\text { in jig }\end{array}$ \\
\hline VII & 1 & $\begin{array}{l}\text { Melakukan proses } \\
\text { pengelasan frame bagian } \\
\text { depan dan dalam. }\end{array}$ \\
\hline VIII & 1 & $\begin{array}{l}\text { Melakukan proses } \\
\text { pengelasan frame bagian } \\
\text { belakang dan dalam }\end{array}$ \\
\hline IX & 1 & $\begin{array}{l}\text { Melakukan proses } \\
\text { pembersihan frame bagian } \\
\text { RH dari spatter, bekas } \\
\text { pengelasan dan } \\
\text { pengecekan. }\end{array}$ \\
\hline $\mathbf{X}$ & 1 & $\begin{array}{l}\text { Melakukan proses } \\
\text { pembersihan frame bagian } \\
\text { LH dari spatter, bekas } \\
\text { pengelasan dan } \\
\text { pengecekan. }\end{array}$ \\
\hline XI & 1 & $\begin{array}{l}\text { Melakukan proses } \\
\text { pengecekan seluruh frame } \\
\text { dari spatter, pin hole, } \\
\text { porosity, beat pengelasan. }\end{array}$ \\
\hline
\end{tabular}

Sedangkan untuk mesin dan alat yang digunakan dalam proses perakitan frame motor KLX di line 1 dapat dilihat pada tabel 3 .
Tabel 3. Mesin dan Alat yang digunakan pada proses pembuatan Frame Motor KLX

(Sumber: PT.KMI)

\begin{tabular}{|c|c|c|c|}
\hline No. & $\begin{array}{c}\text { Mesin } \\
\text { dan Alat }\end{array}$ & Fungsi & $\begin{array}{l}\text { Jumlah } \\
\text { (Unit) }\end{array}$ \\
\hline 1 & $\begin{array}{l}\text { Mesin } \\
\text { Las }\end{array}$ & $\begin{array}{l}\text { Untuk menyambukan } \\
\text { antara material yang } \\
\text { berbahan besi }\end{array}$ & 7 \\
\hline 2 & $\begin{array}{l}\text { Palu } \\
\text { Karet }\end{array}$ & $\begin{array}{l}\text { Meratakan bila ada } \\
\text { material yang tidak } \\
\text { masuk pada jig dan } \\
\text { alat menghilangkan } \\
\text { spater } \\
\end{array}$ & 11 \\
\hline 3 & $\begin{array}{l}\text { Kikir, } \\
\text { Pahat } \\
\text { dan } \\
\text { Ampelas }\end{array}$ & $\begin{array}{l}\text { Untuk membersihkan } \\
\text { frame dari bekas } \\
\text { pengelasan seperti, } \\
\text { spater,scrach,porosity,pin } \\
\text { hole }\end{array}$ & 4 \\
\hline 4 & $\begin{array}{l}\text { Kaca } \\
\text { mata las }\end{array}$ & $\begin{array}{c}\text { Untuk melindungi mata } \\
\text { dari sinar las dan } \\
\text { untuk melihat } \\
\text { beat las. }\end{array}$ & 8 \\
\hline
\end{tabular}

Proses perakitan frame motor KLX di line 1 dilakukan dengan manual dimana pergerakan meterial dilakukan oleh operator sendiri, dari awal proses kerja di stasiun pertama sampai kepada proses terahir di stasiun kerja pada lintasan line 1. Dimana dalam lintasan perakitan line 1 tersebut mempunyai 11 stasiun kerja, dan didalam lintasan perakitan utama tersebut memiliki 11 operator, dengan produksi per-harinya mencapai 52 unit dengan cycle time 517 detik.

\section{Perhitungan Planing Produksi dan Hasil Produksi}

Untuk perhitungan kapasitas produksi perusahaan menggunakan rumus

$$
\text { Kaps Produksi }=\frac{\text { Waktu Kerj: }}{\mathrm{CT}}=\frac{28800}{517}=55,705 \approx 56
$$

Jadi kapasitas produksi saat ini pada lintasan kerja frame motor KLX adalah 56 unit perhari atau 8 jam kerja normal.Pada tabel di bawah ini menjelaskan planing produksi dan 
hasil produksi, pada lintasan kerja line 1,2,3 dan shif dua dari bulan Septeber 2015 - Februari 2016, untuk per-satu lintasan menghasilkan 52 unit frame dan shif dua 50 unit frame.

Tabel 4. Produksi dan Pencapaian Produksi dari September 2015 - Februari 2016 Sumber : PT. KMI

\begin{tabular}{cccc}
\hline No. & Bulan & $\begin{array}{c}\text { Planing } \\
\text { Produksi } \\
\text { (unit) }\end{array}$ & $\begin{array}{c}\text { Actual } \\
\text { Produksi } \\
\text { (Unit) }\end{array}$ \\
\hline 1 & September & 7.562 & 6.708 \\
\hline 2 & Oktober & 8.415 & 6.708 \\
\hline 3 & November & 8.200 & 6.708 \\
\hline 4 & Desember & 8.532 & 6.708 \\
\hline 5 & Januari & 7.853 & 6.708 \\
\hline 6 & Febuari & 8.475 & 6.708 \\
\hline
\end{tabular}

\section{Peta Aliran Proses}

Peta aliran proses perakitan frame motor KLX dilintasan line 1 PT. KMI seperti terlihat pada gambar 3.

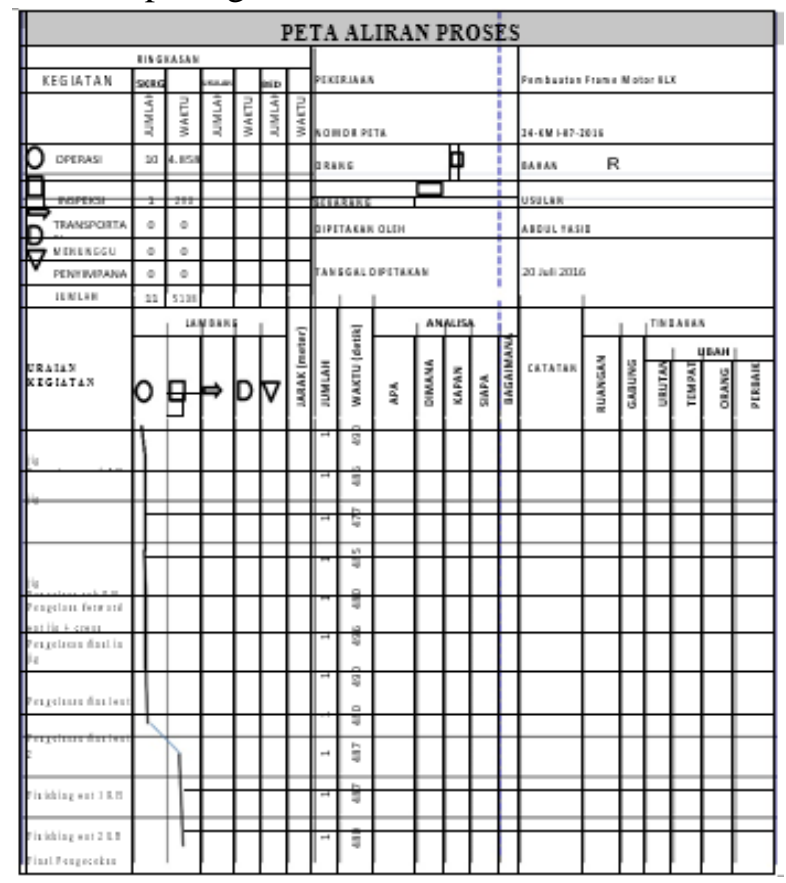

Gambar 3.Peta Aliran Proses Pembuatan Frame Motor KLX. (sumber PT. KMI)

\section{Flow Process Perakitan Frame Motor KLX}

Flow process untuk perakitan frame motor klx PT. KMI adalah seperti terlihat pada gambar 4.

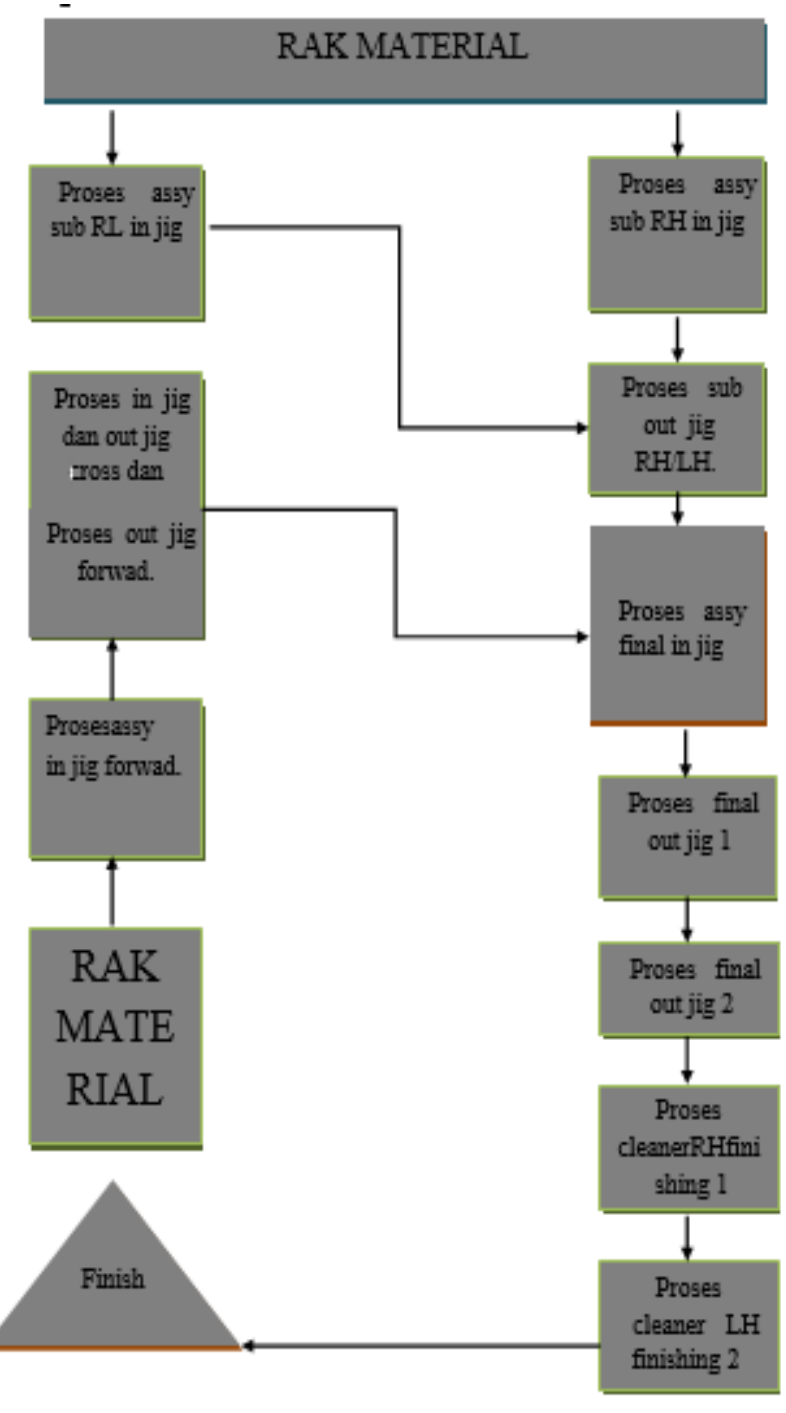

\section{Gambar 4. Flow Process Perakitan Frame Motor KLX Sumber : PT KMI}

\section{Waktu Kerja yang Tersedia}

Pada bulan Juni 2016, terdapat 22 hari kerja yang terdiri dari jam kerja normal yaitu 8 jam kerja per harinya waktu yang tersedia dalam produksi.Adapun rincian kerja tersedia pada bulan juni 2016 dibagian welding di line 1 KLX pada shift 1 bisa dilihat pada tabel 5 . 
Jurnal MATRIK

Volume XIX No.1, September 2018, p 37-48

Tabel 5. Jam Kerja yang Berlaku pada Juni 2016 Sumber: PT. KMI

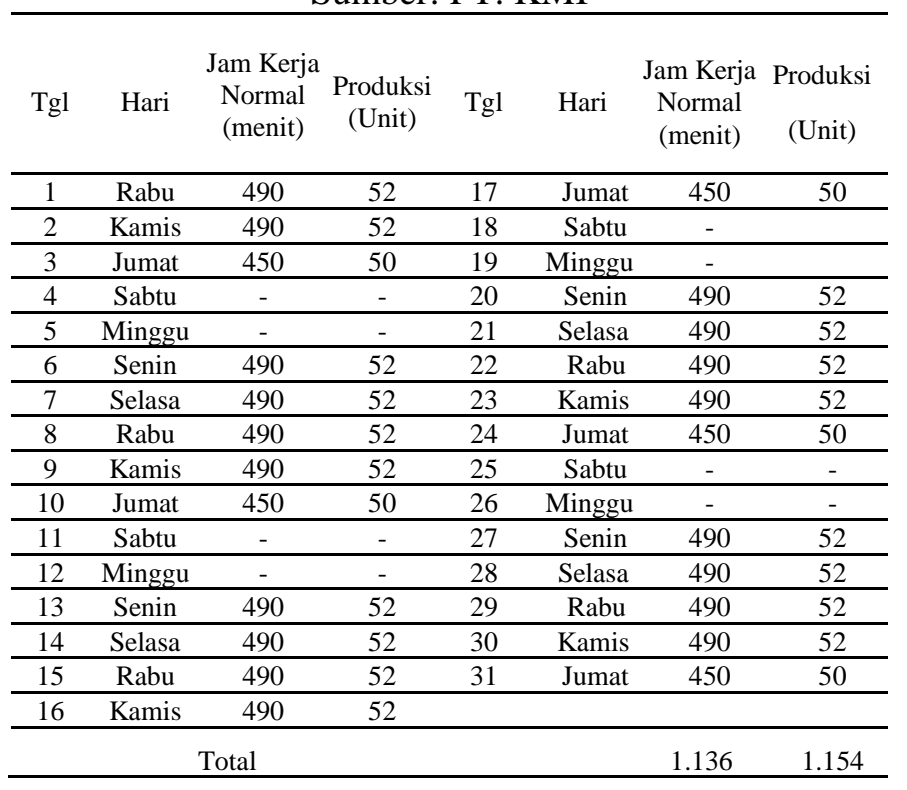

\section{Waktu Siklus Stasiun Kerja}

Waktu siklus dari seluruh stasiun kerja pada proses pembuatan frame Motor KLX di line 1 dijelaskan pada tabel 6.

Tabel 6. Waktu Siklus

Sumber: PT. KMI

\begin{tabular}{clc} 
Stasiun & \multicolumn{1}{c}{ Stasiun Kerja } & $\begin{array}{c}\text { Waktu } \\
\text { Siklus } \\
\text { (detik) }\end{array}$ \\
\hline 1 & Sub RH in jig & 490 \\
\hline 2 & Sub LH in jig & 496 \\
\hline 3 & Sub RH/LH out in jig & 447 \\
\hline 4 & Forward in jig & 515 \\
\hline 5 & Fw out in jig + Cross in, Out jig & 320 \\
\hline 6 & Final assy in jig & 516 \\
\hline 7 & Final assy out in jig 1 & 510 \\
\hline 8 & Final assy out in jig 2 & 510 \\
\hline 9 & Final assy out finishing 1 & 517 \\
\hline 10 & Final assy out finishing 2 & 517 \\
\hline 11 & Inspection & 500 \\
\hline & & 5.338 \\
\hline
\end{tabular}

\section{Pengukuran Waktu Siklus}

Teknik pengukuran waktu siklus yang digunakan dalam penelitian ini dengan cara memakai cara langsung, yaitu teknik pengukuran yang dilakukan dengan mengamati pekerjaan secara langsung dilapangan dan mencatat waktuwaktu kerja
e-ISSN : 2621-8933 p-ISSN: 1693-5128 doi: 10.30587/matrik.v19i1.580

dengan menggunakan jam henti (stopwatch) pada per-stasiun kerja di perakitan frame motor KLX di line 1. Pengamatan waktu siklus untuk masing-masing stasiun kerja terlihat pada tabel 7 .

Tabel 7.Waktu Siklus Kerja

\begin{tabular}{|c|c|c|c|c|c|}
\hline No & $\begin{array}{c}\text { Stasiun } \\
\text { Keria }\end{array}$ & Operator & Elemen Kerja & Nomer Material & $\begin{array}{l}\text { Wakte } \\
\text { (Detik) }\end{array}$ \\
\hline & & & Mas ang material ke iis & & 180 \\
\hline & & & Tack welding & $\begin{array}{l}32170-2094 \\
11056-7180\end{array}$ & 20 \\
\hline & & & Las pipe & $32155-1924$ & 16 \\
\hline & & & Las Brakect & $32170-2094$ & 31 \\
\hline & & & Las Brakect & $32170-2094$ & 12 \\
\hline & & & Tack welding & $11056-7180$ & 14 \\
\hline & & & Las B rakect & $11056-7180$ & 10 \\
\hline & & & Las Brakect & $11056-1096$ & 8 \\
\hline & & & Las Brakect & 11056-7185, & 10 \\
\hline & & & Las Brakect & $11056-7186$ & 8 \\
\hline & & & Las Brakect & $92171-1689$ & 8 \\
\hline & & & Las pipe & $32154-1921$ & 10 \\
\hline \multirow[t]{13}{*}{1} & Sub RH & 1 & Las pipe & $32154-1921$ & 18 \\
\hline & & & Las pipe & $32155-1928$ & 21 \\
\hline & & & Las pipe & $\begin{array}{l}32155-1928, \\
32036-0364\end{array}$ & 10 \\
\hline & & & Las pipe & $33154-1467$ & 10 \\
\hline & & & Las Brakect & $11056-7187$ & 12 \\
\hline & & & Las B rakect & $11056-2354$ & 12 \\
\hline & & & Las pipe & $32155-1924$ & 8 \\
\hline & & & Las pipe & $32036-1364$ & 12 \\
\hline & & & Las Brakect & $11056-1271$ & 10 \\
\hline & & & Tack welding & $11056-7178$ & 14 \\
\hline & & & $\begin{array}{l}\text { Memutar jig } \\
\text { Mengecek }\end{array}$ & & $\begin{array}{l}20 \\
4\end{array}$ \\
\hline & & & $\begin{array}{l}\text { Melepas material dari } \\
\text { Jig }\end{array}$ & & 12 \\
\hline & Total & & 24 & & 490 \\
\hline
\end{tabular}

Untuk mengetahui seluruh waktu siklus pada lintasan kerja Sub LH sampai Inspection proses pembuatan frame motor KLX, dapat dilihat pada lampiran 1A, 1- 10.

\section{Pembuatan Predence Diagram}

Predence diagram adalah gambaran secara grafis dari urutan operasi kerja, tujuan pembuatan predence diagram adalah untuk memidahkan pengontrolan perencanaan kegiatan proses kerja. Dapat dilihat pada gambar 5.

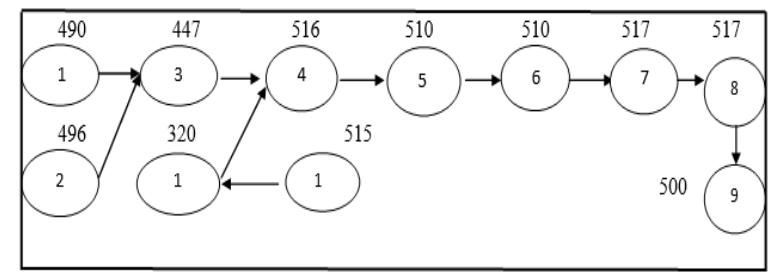

Gambar 5.Predence Diagram Waktu Proses Kerja di line 1

\section{Perhitungan Waktu Siklus.}

Setelah diketahui waktu operasi dari masing-masing stasiun kerja, maka langkah selanjutnya menghitung waktu siklus dan 
esifiensi stasiun kerja.Sedangkan planing produksi pada bualan Desember mencapai 8.533 unit/bulan. Untuk satu Bulan ada 22 hari dengan waktu kerja normal 8 jam, karena pekerjaan dibagi menjadi dua shift.

Tabel 8. Pengukuran Waktu Siklus

\begin{tabular}{|c|c|c|c|c|c|}
\hline $\begin{array}{l}\text { Stasion } \\
\text { Kerja }\end{array}$ & $\begin{array}{l}\text { Proses } \\
\text { (1) }\end{array}$ & $\begin{array}{l}\text { WaltuProses } \\
\text { (detik) } \\
\text { (2) }\end{array}$ & $\begin{array}{l}\text { Cyde Time } \\
\text { (deak) } \\
\text { (3) }\end{array}$ & $\begin{array}{c}\text { IdleTime } \\
\text { (detik) } \\
(3-2)\end{array}$ & $\begin{array}{c}\text { Efisiensi } \\
\text { StasivnKerja } \\
\% \\
(2 / 3.100)\end{array}$ \\
\hline 1 & 1 & 490 & 517 & 27 & 94,777563 \\
\hline 2 & 2 & 496 & 517 & 23 & 95,938104 \\
\hline 3 & 3 & 447 & 517 & 70 & 86,460348 \\
\hline 4 & 4 & 515 & 517 & 2 & 99,613153 \\
\hline 5 & 5 & 320 & 517 & 197 & 61,895551 \\
\hline 6 & 6 & 516 & 517 & 1 & 99,806576 \\
\hline 7 & 7 & 510 & 517 & 7 & 98,646035 \\
\hline 8 & 8 & 510 & 517 & 7 & 98,646035 \\
\hline 9 & 9 & 517 & 517 & 0 & \\
\hline 10 & 10 & 517 & 517 & 0 & \\
\hline 11 & 11 & 500 & 517 & 17 & 96,711799 \\
\hline
\end{tabular}

\section{Perhitungan Work Station Minimum}

Stasiun kerja atau work station adalah lokasi-lokasi tempat elemen kerja dikerjakan. Penentuan jumlah satsiun kerja didapatkan dengan memperhatikan total waktu operasi dengan waktu siklus suatu pekerjaan serta pembagian stasiun kerja.

1. Total waktu siklus perakitan adalah 5.338 detik.

2. Waktu siklus diperoleh dari waktu yang terbesar dari total seluruh stasiun kerja adalah 517 detik

3. Menentukan minimal stasiun kerja yang dibutuhkan didapatkan dengan cara :

Work Station Min. $=\frac{\begin{array}{c}\text { Total Waktu } \\ \text { Operasi }\end{array}}{\frac{\begin{array}{c}\text { Waktu } \\ \text { Siklus } \\ \text { Terbesar }\end{array}}{8}}=\frac{533}{517}=10,3 \approx 11$

Dari perhitungan work stasiun minimum, pada pembuatan frame motor KLX minimum adalah 10 stasiun kerja. Tetapi pada lintasan kerja ini tidak bisa di minimumkan seperti perhitungan di atas.Karena pada proses perakitannya harus berurut dan bertahap tidak bisa didahulukan ataupun dibelakangkan.

\section{Perhitugan Efisiensi Lini dan Balance Delay} Perhitungan waktu efesiensi dimana untuk mengetahui seberapa besar waktu atau persentase waktu menggangur pada proses pembuatan frame motor KLX, yang dikerjakan oleh operator. Untuk mengetahui waktu efisiensi stasiun kerja total, maka dilakukan pengukuran sebagai berikut:

Efisiensi lini $=\underline{\text { Ts1 }} \times 100 \%$

$$
\begin{aligned}
& (\mathrm{k})(\mathrm{ct}) \\
= & \frac{5.338}{(11)(517)} \times 100 \% \\
= & 93,86 \%
\end{aligned}
$$

$$
\begin{aligned}
\text { Balance delay } & =100 \%-\text { efisiensi lini } \\
& =100 \%-93,86 \% \\
& =6,14 \%
\end{aligned}
$$

Jadi waktu efisiensi stasiun kerja total adalah sebesar $6,14 \%$.

\section{Perhitungan Smoothnees Index}

Perhitungan untuk metode smoothness

\begin{tabular}{|c|c|c|}
\hline Stasiun Kerja & CT-S I (detik) & $(\mathrm{CT}-\mathrm{SI})^{2}$ (detik) \\
\hline 1 & 27 & 792 \\
\hline 2 & 23 & 441 \\
\hline 3 & 70 & 4.900 \\
\hline 4 & 2 & 4 \\
\hline 5 & 197 & 38.809 \\
\hline 6 & 1 & 1 \\
\hline 7 & 7 & 49 \\
\hline 8 & 7 & 49 \\
\hline 9 & 0 & 0 \\
\hline 10 & 0 & 0 \\
\hline 11 & 17 & 289 \\
\hline \multicolumn{2}{|c|}{$\begin{array}{c}\text { Stasiun Kerja } \\
?\end{array}$} & $\begin{array}{r}\text { (CT-SI) (detik) } \\
45.334\end{array}$ \\
\hline \multicolumn{2}{|c|}{$\mathrm{v}$} & 212 \\
\hline
\end{tabular}
index ini adalah untuk mengetahui index yang menunjukan kelancaran dari suatu keseimbangan pada lintasan kerja.Perhitungan smoothness index dapat dilihat pada table 4.10 sebagai berikut

Tabel 9. Perhitungan Smoothnes Index

Nilai smoothness indexs sebesar:

Smoothness indexs $=(\mathrm{ct}-\mathrm{si})^{2}$

$$
\begin{aligned}
& =(45.334)^{2} \\
& =212 \text { detik. }
\end{aligned}
$$

Pada perhitungan Smoothness indexs diatas menunjukan kelancaran pada lintasan kerja sebesar 212 detik. 


\section{Analisis Metode 5W-1H}

Analisis masalah menggunakan

$5 \mathrm{~W} 1 \mathrm{H}$ yang pada umumnya mempertanyakan dan menyelidiki :

1. What ? Apa Tujuannya ?

Untuk menyeimbangkan beban kerja yang terjadi idle time di salah satu stasun kerja, pembuatan frame motor KLX di line 1.

2. Why? Mengapa harus di seimbangkan?

Karena dengan adanya idle

time di salah satu stasiun kerja, mengakibatkan tidak seimbangnya beban kerja di line KLX, maka akan berdampak hasil produksi tidak maksimal.

3. Where ? Dimana terjadinya Idle time?

Pada lintasan kerja line 1 KLX di stasiun kerja 5 forward in jig.

4. When ? Kapan terjadinya Idle time? line $1 \mathrm{KLX}$

Pada saat proses produksi di

5. Who ? Siapa penanggung jawab pada proses tersebut?

Penanggung jawab pada setiap proses adalah Operator, leader line, forman dan diserahkan kepada kepala bagian produksi dan semua bagian produksi yang terkait.

6. How ? Bagaimana cara perbaikannya ?

Mengalokasikan beban kerja yang paling banyak dan di tambahkan ke beban kerja terdapat terdapat idle time.

\section{Usulan Perbaikan Pada Proses Kerja.}

Peneliti mengusulkan perbaikan pada proses kerja pada bagian forwad in jig dan cross in out jig di stasiun kerja 5. Pada proses yang sudah berjalan saat ini banyak terjadi waktu menganggur, dikarenakan proses di stasiun kerja 5, lebih cepat dibandingkan dengan proses lainnya. Hal inilah yang menjadi acuanbagi peneliti untuk melakukan usulan perbaikan proses kerja terhadap stasiun kerja lainnya. Berikut adalah usulan perbaikan yang akan dilakukan oleh peneliti.

1. Menambahkan beban kerja pada stasiun kerja 5 pada proses forward out jig dengan mengurangi beban kerja dari stasiun kerja 9 dan 10 pada proses pembersihan spater dia area forward
RH,LH dengan waktu 120 detik. Dan penambahan dari stasiun kerja 7 dengan waktu 40 detik, jadi total penambahan beban kerja menjadi $120+40=160$ detik,

2. Menambahkan beban kerja pada stasiun kerja 3 pada proses sub RHLH out jig dengan mengurangi beban kerja dari stasiun kerja 4 forward in jig pada proses las pipe dengan waktu 30 detik.

3. Menambahkan beban kerja pada stasiun kerja 7 pada proses final out jig 1 dengan mengurangi beban kerja dari stasiun kerja 6 final assy in jig pada proses las pipe dan las bracket dengan waktu 20 detik.

4. Menambahkan beban kerja pada stasiun kerja 8 pada proses final out jig 2 dengan mengurangi beban kerja dari stasiun kerja 2 sub in jig pada proses las bracket dengan waktu 10 detik.

5. Menambahkan beban kerja pada stasiun kerja 9 dan 10 pada proses finishing out jig dengan mengurangi beban kerja dari stasiun kerja 8 pada proses membersihkan area brakect scracth RHLH dengan waktu 40 detik. Dan penambahan dari stasiun kerja 11 pada dengan proses pengecekan dimensi dengan waktu 20 detik, jadi penambahan pada beban kerja pada stasiun kerja 9 dan 10 menjadi $40+20=60$ detik.

\section{KESIMPULAN DAN SARAN Kesimpulan}

Setelah mengumpulkan data dan data dianalisis proses pembuatan frame motor KLX, yang dilakukan di bagian welding maka peneliti menyimpulkan sebagai berikut:

1. Memperbaiki proses kerja pada pembuatan frame motor KLX, maka akan menghasilkan efisiensi lini yang meningkat, yang awalnya 93,86\% menjadi $97,83 \%$ dan balance delay menurun yang awalnya $6,14 \%$ menjadi $2,17 \%$.

2. Untuk perhitungan kapasitas produksi pada proses pembuatan frame motorKLX, meningkat yang awalnya 55 unit perhari atau per 8 jam kerja normal menjadi 58 unit perhari dengan kerja normal.

3. Menambah beban kerja pada stasiun 
yang mengalami beban kerja yang sedikit, maka akan terciptalah lintasan kerja yang seimbang dan idle time nya menurun yang awalnya stasiun kerja 5 waktu 197 detik menjadi 16 detik .

\section{Saran}

Berdasarkan hasil pengumpulan dan pengolahan data diatas dengan menggunakan metode keseimbangan lintasan (line balancing), penulis memberikan beberapa saran yang diharapkan proses pada pembuatan frame motor KLX lebih optimal dalam pembagian beban kerja.

1. Untuk meningkatkan kapasitas produksi maka lintasan kerja yang mengalami idle time harus diminimumkan, dengan cara pengalokasian beban kerja dari stasiunstasiun yang ada di line 1 KLX.

2. Dari 11 stasiun kerja pada proses pembuatan frame motor KLX, yang sekarang berjalan harus diseimbangkan,terdapat dua stasiun kerja yang tidak merata pembagian beban kerjanya, yaitu di stasiun 2 hingga stasiun 10. Agar proses produksi diline 1 KLX, tidak mengalami Bottelneck.

3. Untuk pemindahaan beban kerja, operator sebaiknyaditraning terlebih dahulu agar pemindahan beban kerja, berjalan sesuai perhitungan yang telah dilakukan.

\section{DAFTAR PUSTAKA}

Assauri,S.2004, Manajemen Produksidan Perancangan Sistem Produksi, Yogyakarta: BPEE.

Ginting, Rosnani. 2007, Sistem Produksi, Edisi Pertama - Yogyakarta; Graha Ilmu.

Gasperz, V. 2004, Production Planning And Inventory Control. Jakarta: PT Gramedia Pustaka Utama.

Handoko,T Hani. 1999, Dasar-Dasar Manajemen Produksi dan Operasi. Yogyakarta; BPEFE.

Iftikar Z. Sutalaksana.2006, Ruhana Anggawisastra, Jann $\mathrm{H}$. Tjakraatmaja, Teknik Perancangan Sistem Kerja, edisi ke-2,ITB.

Ristono,Agus2010, sistem Produksi Tepat Waktu, edisi pertama, Yogyakarta;
Graha Ilmu.

Sritomo Wignjosoebroto. 2003, Ergonomi Studi Gerak dan Waktu, edisi 3, GunaWidya, Jakarta.

Sri Hartini, Kadarsah Suryadi. 2011, Teknik Mencapai Produksi Optimal, Lubuk Agung, Bandung. 